\title{
Politeness Strategies of Disagreement by English Native Speaker Students
}

\author{
Nadia Yofa Laela Khoirunnisa*, Tofan Dwi Hardjanto \\ Universitas Gadjah Mada, Indonesia \\ *Email: nadia.yofa.1@gmail.com
}

\begin{abstract}
A B S T R A C T
This research paper investigates the speech act of disagreement performed by English native speaker students. Particularly, it attempts to examine the politeness strategies used by English native speaker students in realizing disagreement. The data were obtained using Discourse Completion Task consisting of six situations that were completed by twenty students. The results showed that a total of 113 utterances of disagreement were found. The most frequently used strategy was negative politeness (41.6\%) since this strategy becomes the most suitable strategy to minimize the imposition of disagreement utterances. The rank is then followed by positive politeness (29. 2\%), bald on-record (25.7\%), and off-record (3. 5\%).
\end{abstract}

Keywords: disagreement, DCT, politeness, politeness strategies, speech acts.

\section{INTRODUCTION}

Speech acts of disagreement can be found with ease in public discussions, office employee meetings, or even private conversations performed between close friends even though they are actually undesirable reactions conveyed by the speakers in a set of communication. These acts can potentially cause the hearer to feel offended and can pose a threat to the hearer's face as well. As Brown and Levinson (1987, p. 61) state, face is the public self-image that every member wants to claim for himself. This concept of face consists of two aspects, namely: a) positive face: "the positive consistent self-image or 'personality' (crucially including the desire that this self-image be appreciated of) that is claimed by interactants" (Brown and Levinson, 1987, p. 61) and b) negative face: "the basic claim to territories, personal preserves, rights to non-distraction" (Brown and Levinson, 1987, p. 61). Therefore, because of this vulnerability of face, speakers should employ politeness strategies in realizing disagreement to avoid any intention of clash and FTAs (Face
Threatening Acts) or at least to mitigate the threat or "blur" the threat. So, peaceful atmosphere between the speaker and the hearer can be built, without any intention to damage one's face.

Accordingly, the present research attempts to investigate how English native speaker students express disagreement in formal and informal situations. Moreover, compared to other speech acts such as requests, compliments, refusals, and so on, disagreement has been relatively less studied. The speech act of disagreement is often said to be similar to that of refusal because both speech acts are the acts of having a contrary answer over someone's utterance. However, according to Sifianou (2012, p. 1554), disagreement is "an expression of a view that differs from that expressed by another speaker". Refusal, on the other hand, is when someone refuses to do or accept something. Then, the object of negating in disagreement is often someone's opinion while the object of refusal is often a request.

English native speakers were chosen as the respondents with the notion to build more 
understandable communication between the English language learners and the English native speakers. As Hofstede (in Nadar 2009, p. 182) argues, someone must have carried patterns of thinking, feeling, and acting which were learned throughout their lifetime. Therefore, English native speakers must have brought up a certain pattern of thinking, feeling, and acting when producing utterances. Then, language production from those who are English native speakers can be a learning tool to elevate language learners' pragmatic competence in using the language they learn. Therefore, using English native speaker as the respondents for this present research is hoped to be a contribution for English language learners in increasing the ability to use the language according to that certain pattern carried by the native speakers.

In response to the background of study, this research attempts to present the politeness strategies used by English native speaker students in realizing disagreement. Particularly, the objectives of the research are (1) to investigate what politeness strategies are used by English native speaker students in realizing disagreement and (2) to examine which strategy is the most commonly used and why.

In addition to the definition of disagreement mentioned above, disagreement is basically an undesired response from a statement (Pomerantz 1984). On the other hand, politeness as proposed by Yule (1996, p. 60) is demonstrating awareness of another person's face. Therefore, politeness strategies happens to be very important in performing disagreement because it can carry a threat for the addressee's positive face and negative face since it indicates that the speaker does not share the same belief or want with the addressee. Positive face is recognized as the need of a person to be approved of, to have others share the same wants. Negative face is recognized as the desire of a person to be unimpeded, to avoid being imposed upon by others (Brown and Levinson 1987, p. 61).

Other than that, Rees Miller (in Sifianou 2012, p. 1557) states that power has an essential role in determining the choice of strategy in realizing disagreement. For instance, if the hearer has a lower power (-P) than the speaker, the speaker inclines to use positive politeness strategy while for the hearer who has higher power $(+\mathrm{P})$, the speaker tends to use negative politeness (Brown and Levinson 1987, p. 250). In relation with the performance of face threatening acts (FTA), Brown and Levinson develop a politeness strategy consisting of four sub-strategies.

The first strategy of Brown and Levinson's politeness strategies is when FTA is done baldly; without redressive action or known as bald onrecord. This strategy does not attempt to minimize the threat on the hearer's face and most likely occurs when both the speaker and the hearer are in a close relationship such as between close friends and family. Bald on-record is mostly used when the speaker is in a hurry or an emergency situation. The prime reason for using bald onrecord is to maximize the efficiency of the FTA done by the speaker without emphasizing the need to save the hearer's face (Brown and Levinson 1987, p. 95). The second strategy is positive politeness. Positive politeness is aimed to save a person's positive face meaning that her/his perennial desire; wants, actions, acquisitions, and values should be considered desirable (Brown and Levinson 1987, p. 101). The prime function of positive politeness strategy is to minimize the distance and to extend intimacy between the speaker and the hearer. The third strategy is negative politeness. Negative politeness is directed to a person's negative face; her/his wants to have her/his freedom unhindered and her/his attention unimpeded. The prime function of negative politeness is to minimize imposition that FTA affects (Brown and Levinson 1987, p. 129). The last strategy is off-record. Off-record is done when it is unattainable to attribute only one unambiguous intention or meaning of S's utterance. The speaker deliberately avoids being committed to just one interpretation of her/his act. In other words, the speaker wants or has to do a FTA but s/he does not want to be responsible for her/his utterance; s/he leaves it to the $\mathrm{H}$ to interpret (Brown and Levinson 1987, p. 211). 


\section{METHODS}

In conducting the research, there are two steps of data collection and data analysis. All data were collected using an instrument called DCT (Discourse Completion Task) which was designed into a web-based questionnaire. The DCT consisted of six situations. Three situations $\left(1^{\text {st }}, 2^{\text {nd }}\right.$, and $\left.6^{\text {th }}\right)$ were modified from Kreutel (2007), one $\left(3^{\text {rd }}\right)$ from XueHua (2006), one ( $\left.5^{\text {th }}\right)$ from Bavarsad (2015), and the last one was designed specifically for this research in consultation with an American native speaker informant (language helper). Then, it was distributed to English native speaker students from USA, Great Britain, and Australia. From a total of 40 respondents, only 20 respondents (8 students from USA, 5 from Great Britain, and 7 from Australia) were considered presenting valid responses. The respondents are also limited into only university students with an age range 18-26 years old. From 20 respondents, there were 113 valid utterances in total.

After all the data were collected, as mentioned before, they were classified based on Brown and Levinson's politeness strategies: a) Bald on-record, b) Negative politeness, c) Positive Politeness, and d) Off-record. Bald on-record politeness strategy comprises bold and direct disagreement, sarcasm, and so on. Negative politeness strategy comprises five sub-strategies and ten output strategies. This strategy is intended in saving the hearer's negative politeness. Utterances classified into negative politeness strategy are the ones that show disagreement by using apology, question, hedge, and so on. Positive politeness strategy comprises three sub-strategies and fifteen output strategies. For disagreement utterances that show the output strategies like avoid disagreement, promise, be optimistic, etc will be classified into positive politeness strategies. Thus, for disagreement utterances considered as hint and avoidance will be classified as off-record strategy. In order to make the analysis easier, all data of disagreement were analyzed, classified, and coded based on the strategies being used. The following is an example of the encoded datum:
"Thanks for the recommendation, but I'm going to go with something else." (S5. PP06. 29)

S5 means situation 5 .

PP means Positive politeness strategy.

06 means that the utterance is the $6^{\text {th }}$ utterance using positive politeness strategy within situation 5 .

29 means that the utterance is the $29^{\text {th }}$ utterance using positive politeness strategy within all situation.

\section{RESULTS AND DISCUSSION}

This section aims at presenting and discussing all types of politeness strategies of disagreement used by English native speaker students. The disagreement utterances were classified into four categories of politeness strategies proposed by Brown and Levinson (1987). The classified data are presented in the form of table and divided into four sub-sections: bald on-record, negative politeness, positive politeness, and off-record. The most commonly used strategy and the reason are also presented here.

Table 1. The frequency and distribution of politeness strategies used by English native speaker students

\begin{tabular}{|c|c|c|c|}
\hline No. & Politeness Strategies & Freq. & $\%$ \\
\hline 1. & Strategy 1: Bald on-record & 29 & 25.7 \\
\hline 2. & Strategy 2: Negative Politeness & 47 & 41.6 \\
\hline 3. & Strategy 3: Positive Politeness & 33 & 29.2 \\
\hline \multirow[t]{2}{*}{4.} & Strategy 4: Off-record & 4 & 3.5 \\
\hline & Total & 113 & 100.0 \\
\hline
\end{tabular}

The table shows that there were a total of 113 utterances of disagreements. The first strategy, bald on-record, was used in 29 utterances or 25 . $7 \%$. The second strategy, negative politeness, contributed $41.6 \%$ to the total percentage with 47 utterances. Then, the third strategy, positive politeness, was used in 33 utterance and contributed 29. $2 \%$ to the total percentage. The forth strategy, off-record, was used in only 4 utterance or 3. 5\%. If all strategies are ranked, negative politeness became the most 
frequent strategy used by English native speaker students, then followed by positive politeness, bald on-record, and off-record. The following paragraphs present the discussion of each strategy including the output strategies used in realizing disagreement by English native speaker students. It is presented with one example for each output strategy.

\section{Bald on-record}

The use of bald on-record strategy most likely appear within a conversation between people who know each other closely and have a more intimate relationship (e. g. close friends and family). In terms of distance (D) and power (P), bald on-record utterance mostly occurs if the speaker has close distance (-D) and equal distance $(=D)$ and/or higher power $(+P)$ and equal power $(=\mathrm{P})$ with the interlocutor. The table below shows the frequency and distribution of bald on-record strategy found in this research.

Table 2. The frequency and distribution of bald onrecord strategy used by English native speaker students

\begin{tabular}{lrr}
\hline Situations & Freq. & \multicolumn{1}{c}{$\%$} \\
\hline Situation 1 & 1 & 3.45 \\
\hline Situation 2 & 12 & 41.38 \\
\hline Situation 3 & 6 & 20.69 \\
\hline Situation 4 & 1 & 3.45 \\
\hline Situation 5 & 5 & 17.24 \\
\hline Situation 6 & 4 & 13.79 \\
\hline Total & 29 & 100.00 \\
\hline
\end{tabular}

The table indicates that bald on-record strategy occurred in all the six situations with a total of 29 utterances. Speakers mostly used bald on-record in Situation Two with 12 utterances and contributed $41.38 \%$ to the total percentage. 6 bald on-record utterances or $20.69 \%$ were used in situation three, 5 or $17.24 \%$ in situation five, 4 or 13. $79 \%$ in situation six, and 1 or $3.45 \%$ in both situation one and four. Presented and discussed below is an example illustrating the use of bald on-record strategy by the students.

(1) (In a car: a student disagrees with her/his brother over a short-cut, -P, -D)
No, that's the wrong way, go left. (S2. BR08.

09)

The situation occurs between an elder brother/sister $(\mathrm{S})$ and a younger brother $(\mathrm{H})$ in a road when the speaker is asked to disagree on the younger brother's decision to turn right and claim that it is the shortcut. The respondent chooses to use direct disagreement in disagreeing since s/he disagrees toward someone who is younger than $\mathrm{him} / \mathrm{her}$ and it is considered safe to employ this strategy.

\section{Negative Politeness}

This strategy is often found when the speaker is talking to superiors (Brown and Levinson 1987, p. 250). However, this strategy can also be used when the hearer and the speaker has symmetrical power $(=\mathrm{P})$ over the speaker and the distance between both the speaker and the hearer is high (+D) (Brown and Levinson 1987, p. 250). The following table shows the frequency and distribution of negative politeness strategy found in this research.

Table 3. The frequency and distribution of negative politeness strategy used by English native speaker students

\begin{tabular}{lrr}
\hline Situations & Freq. & \multicolumn{2}{c}{$\%$} \\
\hline Situation 1 & 8 & 17.02 \\
\hline Situation 2 & 7 & 14.89 \\
\hline Situation 3 & 4 & 8.52 \\
\hline Situation 4 & 10 & 21.28 \\
\hline Situation 5 & 3 & 6.38 \\
\hline Situation 6 & 15 & 31.91 \\
\hline Total & 47 & 100.00 \\
\hline
\end{tabular}

Altogether there were 47 utterances expressed by negative politeness strategy. 15 (31. 91\%) utterances were found in situation six (involving a student and a lecturer with $+\mathrm{P}$ and $+\mathrm{D}), 10(21.28 \%)$ in situation four, 8 (17. 02\%) in situation one, $7(14.89 \%)$ in situation two, 4 (8. $52 \%)$ in situation three, and $3(6.38 \%)$ in situation five. The negative politeness strategy covers five sub-strategies and ten output strategies (Brown and Levinson 1987, p. 131). From all output strategies covered within this strategy, only 
'Question and Hedges', 'Give deference', and 'Apologize' are found to be frequently employed by the students.

\section{Questions and Hedges}

This output strategy is derived from the want to not presume/assume and also coerce. Question, in terms of negative politeness, can possess different propositional content which is more than just a simple question. An example of the use of 'Question and hedges' is presented below:

(2) (In a class: A student disagrees with a lecturer over an $\mathrm{F}$ score $\mathrm{s} /$ he got $,+\mathrm{P},+\mathrm{D}$ )

Can you please check again? I swear that I sent the paper to you on Monday. (S6. NP09. 41)

Here, the situation is between a student (S) and a lecturer $(\mathrm{H})$. In this case, the speaker is talking to someone with higher power $(+)$ and far distance $(+)$. When realizing disagreement, the speaker starts by asking a question which is at the same time demonstrating a request to check the paper again before stating what s/he disagrees with. Negative politeness strategy, in this case, is used because the hearer has a higher power $(+\mathrm{P})$ and the distance between the speaker and hearer is not close $(+\mathrm{D})$.

\section{Give Deference}

There are two ways to realize deference: one is to be humble to $\mathrm{H}$ and $\mathrm{S}$ abases himself and $\mathrm{S}$ raises $\mathrm{H}$; paying respect to $\mathrm{H}$ and treats $\mathrm{H}$ as superior and conveys that $\mathrm{H}$ has a higher status than S. This output aims to minimize the potential threat of FTA by indicating that $\mathrm{H}$ is immune to any imposition due to her/his superiority (Brown and Levinson 1987, p. 178). The following excerpt is the example:

(3) (In a class: a student disagrees with a lecturer over an $\mathrm{F}$ score $\mathrm{s} /$ he got, $+\mathrm{P},+\mathrm{D}$ )

Excuse me professor but you received my paper on Monday. I turned it in early in class. Please check if you have misplaced it. (S6. NP11. 43)
In the utterance above, the student chooses to show deference by addressing the lecturer first using a title "Professor" before they perform disagreement. A lecturer has a full authority to give score for the students that it is considered impudent to complain or show disagreement with what the lecturer has decided. By giving deference, the speaker demonstrates an FTA without being deliberate to impose on the hearer. It also implies that although the speaker shows a contradictive argument, s/he still positions the hearer as someone respected.

\section{Apologize}

The 'Apologize' output strategy indicates the speaker's reluctance in impinging H's negative face. Therefore, the speaker redresses by apologizing if the speaker might impose the hearer. One example of the 'Apologize' output strategy is shown below:

(4) (In a restaurant: a student disagrees with a waiter over his menu recommendation, $-\mathrm{P}$, $+\mathrm{D})$

I really don't like fish I'm sorry, is there anything else? (S6. NP03. 32)

The speakers shows disagreement at first then s/he redresses the FTA by apologizing to $\mathrm{H}$ in order to save the hearer's face.

\section{Positive Politeness}

Positive politeness most likely occurs in a situation where the speaker and the hearer has a low distance relation (-D) and lower power (-P) (Brown and Levinson 1987, p. 250). In using positive politeness strategy, the speaker brings up the sphere of appreciation of the hearer's want and proposes similarity between speaker's ego and interlocutor's wants (Brown and Levinson 1987, p. 101). In social context, positive politeness is used to indicate the speaker to 'get closer' to the hearer (Brown and Levinson 1987, p. 103). Below is a table showing the frequency and distribution of positive politeness strategy found in this research. 
Table 4. The frequency and distribution of positive politeness strategy used by English native speaker students

\begin{tabular}{crr}
\hline Situations & Freq. & \multicolumn{2}{c}{$\%$} \\
\hline Situation 1 & 7 & 21.21 \\
\hline Situation 2 & 0 & 0 \\
\hline Situation 3 & 10 & 30.30 \\
\hline Situation 4 & 5 & 15.15 \\
\hline Situation 5 & 10 & 30.30 \\
\hline Situation 6 & 1 & 3.04 \\
\hline Total & 33 & 100.00 \\
\hline
\end{tabular}

The table shows that there were a total of 33 utterances of disagreement expressed by positive politeness. Both situation three and five got the highest number with 10 utterances or $30.30 \%$. Then, it was followed by situation one with 7 utterances or $21.21 \%$, situation four with 5 utterances or $15.15 \%$, and situation six with only 1 utterance or 3. $04 \%$. Positive politeness strategy covers three sub-strategies and fifteen output strategies. However, the output strategies that were highly used were promise and be optimistic (from the sub-strategy, 'Convey that $\mathrm{S}$ and $\mathrm{H}$ are cooperators'), avoid disagreement (from the substrategy, 'Claim common ground') and give gifts to $\mathrm{H}$ (from the sub-strategy, 'Fulfil H's wants for some X').

\section{Promise}

The speaker can stress her/his cooperation by promising the hearer; claiming that whatever the hearer's want is, the speaker desires it also and will help to obtain. Even though some promises might be false, it still shows a good intention of the speaker to satisfy the hearer's positive face (Brown and Levinson 1987, p. 125). The use of this output strategy is presented below:

(5) (At home: a student disagrees with his/her father that s/he should quit organization and focus only on study, $+\mathrm{P},-\mathrm{D}$ )

Dad, I promise that I will work harder. The clubs I'm involved in help me to grow as a complete person at school. Please let me stay in them. (S3. PP09. 16)
The speaker in above excerpt disagrees with her/his father's opinion that $\mathrm{s} / \mathrm{he}$ gets a bad score due to her/his lots of activities and organizations. To express contrary arguments, s/he chooses 'promise' as the tool, providing future commitment that s/he "will work harder" to elevate her/his score in order to make her/his father accept their disagreements.

\section{Be Optimistic}

The speaker becomes 'optimistic' that the hearer will cooperate with her/him about what the speaker believes and at the same time the speaker will cooperate with the hearer as well (Brown and Levinson 1987, p. 126). The following excerptis an example of the use of this output strategy:

(6) (On campus: a student disagrees with a new student on campus over her argument that school is a waste of time and money, $=\mathrm{P},+\mathrm{D}$ )

Oh I guess that is cool, but I feel like this place will end up being really fun and we will learn a lot!(S4. PP03. 20)

The utterance above is between two new students, the speaker disagrees with the hearer who declares that school is useless and such a waste of money. The speaker chooses to use 'Be optimistic' strategy to redress the FTA. The speaker tries to come up with all positive possibility of going to school by saying that school "will end up really fun and full of knowledge".

\section{Avoid Disagreement}

The 'Avoid disagreement' output strategy covers four strategies: token agreement, pseudoagreement, white lies, and hedging opinion (Brown and Levinson 1987, p. 113-116). However, token agreement was found to be most commonly used strategy in the present research. The examples of token agreement include "I like it, but...", "It looks good, but...", "I agree I need to focus... However,...", etc. The following example is presented for a deeper understanding:

(7) (At home: a student disagrees with her/his father to quit organization and focus only on study, $+\mathrm{P},-\mathrm{D})$ 
I agree I need to focus more on my studies. However, I need to learn how to manage my time. I am going to put more emphasis on studying while still being involved in my extracurricular activities. Because there is more to life that studying for a test. (S3. PP03. 10)

The situation above involves a student (S) and her/his father $(\mathrm{H})$. Since the hearer possesses a higher power $(+\mathrm{P})$ than the speaker, the speaker should modify the utterance so that it will not appear rude. The speaker employs a token agreement by claiming that the hearer is true and saying "I agree I need to focus more on my studies" at the beginning before finally saying the contrary.

\section{Give Gifts to the Hearer}

The speaker gives gifts to the hearer to demonstrate that $\mathrm{s} / \mathrm{he}$ knows what the hearer wants. It is not only about tangible gift but more about human-relations wants such the desire to be liked, appreciated, admired, understood, and so on (Brown and Levinson 1987, p. 129). An example is presented below:

(8) (In a restaurant: a student disagrees with a waiter over a new recommendation menu that he suggests, $-\mathrm{P},+\mathrm{D}$ )

Thanks for the recommendation, but I'm going to go with something else. (S5. PP06. 28)

The situation involves a customer (S) and a waiter $(\mathrm{H})$, the speaker wants to show indirect disagreement to what is offered by the waiter by using a mitigation. $\mathrm{S} /$ he mitigates the utterance by giving gifts which is an appreciation "Thank you" of the waiter's effort to recommend/suggest a new menu.

\section{Off-record}

Going off-record means to go a way that is impossible to attribute one definite intention to an act (Brown and Levinson 1987, p. 211). An offrecord utterance tends to be ambiguous, allowing more than one interpretation. According to Brown and Levinson (1987, p. 250), off-record politeness is commonly found in a situation in which the speaker has a lower power (-P) over the hearer and the distance between them is low (-D). The use of off-record strategy was found in Situation Four and Five. Both Situation Four and Five involve people who have a high distance relation $(+\mathrm{D})$. The following table shows the frequency and distribution of off-record strategy found in this research.

The table shows that off-record strategy got the smallest portion in the use of politeness strategy with only 4 utterances. Each two utterances occurred in both Situation Four and Five.

Table 5. The frequency and distribution of off-record strategy used by English native speaker students

\begin{tabular}{|c|c|c|}
\hline Situations & Freq. & $\%$ \\
\hline Situation 1 & & 0 \\
\hline Situation 2 & & 0 \\
\hline Situation 3 & & 0 \\
\hline Situation 4 & & 50 \\
\hline Situation 5 & & 50 \\
\hline Situation 6 & & 0 \\
\hline Total & & 4100.00 \\
\hline
\end{tabular}

\section{Hinting}

The 'Hinting' strategy occurs when someone says something that is not explicitly relevant and can be defined as "open" or needing interpretation of the possible relevance from the hearer (Brown and Levinson 1987, p. 213). Below is the example of 'Hinting':

(9) (In a restaurant: a student disagrees with a waiter over a new recommendation menu that he suggests, $-\mathrm{P},+\mathrm{D}$ )

I would like more time to decide what to order, please come back in about 2 minutes. (S5. OR01. 03)

The utterance above can be classified as giving a hint. The speaker is asked to disagree to what is offered by the waiter but $\mathrm{s} /$ he chooses to go indirect by saying an equivocal utterance. $\mathrm{S} / \mathrm{he}$ lets the waiter to interpret and draw a conclusion by herself. However, since the expected utterance from the speaker is disagreement so the utterance 
can be understood as an indirect disagreement toward the waiter's (hearer's) utterance.

\section{Avoidance}

'Avoidance' is basically making no commitment on others' opinion. It is used when the speaker does not want her/his utterance to be embedded to others' thought. The speaker avoids being committed to and responsible for her/his utterance. The use of this output strategy is shown in the example below:

(10) (On campus: a student disagrees with a new student on campus over her argument that school is a waste of time and money, $=\mathrm{P},+\mathrm{D}$ )

I'm sorry you feel that way. (S4. OR01. 01)

The utterance "I'm sorry you feel that way" shows a kind of avoidance in which the speaker has a different opinion from the hearer but does not want to be too attached to what $s /$ he said. The utterance appears to be a sympathy that does not state whether the speaker disagrees or agrees. The speaker just wants to appear to be responsive without encroaching upon the hearer's freedom to have her/his face safe.

\section{CONCLUSION}

This research investigates politeness strategies used by English native speaker students in realizing disagreement. A total of 113 utterances were used to express disagreement. The most frequently used strategy was negative politeness (41. 6\%), followed by positive politeness (29. $2 \%$ ), bald on-record (25. $7 \%$ ), and off-record (3. 5\%).

Negative politeness strategy became the most suitable strategy to minimize the imposition of disagreement utterances. Besides, this strategy is mostly used in situations that mostly involve hearers with higher power $(+\mathrm{P})$ or equal power $(=\mathrm{P})$, or long social distance $(+\mathrm{D})$. Within the negative politeness strategy, the most frequently used output strategies are 'Questions and hedges', 'Give deference', and 'Apologize.

The findings support Kreutel (2007) who found that native speakers use more mitigational devices in realizing disagreement. Moreover, The 'Hedges' strategy was the most frequently-used.
Other mitigational devices such as 'suggestions' and 'explanation' are commonly found as well in Kreutel's study. In this study, speech acts such as 'suggestions' and 'explanations' were also common as the tools to perform disagreement but these devices are not the main focus to be analyzed.

Nevertheless, this research focuses only on the politeness strategies used for disagreement that were performed by English native speaker students. It is also admitted that the significance of this research is limited only to the kinds of politeness strategies used by the respondents in disagreeing. Therefore, further research aimed to develop the results of this study is needed. Studies concerning the motives of choosing the politeness strategies or the pattern of disagreement utterances observed through another theory would be preferable in supporting this limited study.

\section{REFERENCES}

Basarvad, S. , Eslami-Rasekh, A. , \& Simin, S. (2015). The Study of Disagreement Strategies to Suggestions Used by Iranian Male and Female Learners. International Letters of Social and Humanistic Sciences 49, pp. 30-42.

Brown, P. and Levinson, S. C. (1987). Universal in Language usage: Politeness phenomena. In E. N. Goody (Ed). Question and Politeness: Strategies in Social Interaction. Cambridge: Cambridge University Press.

Kreutel, K. (2007). “I'm not agree with you”. ESL Learners' Expression of Disagreement. TESL-EJ 11 (3), pp. 1-35.

Nadar, FX. (2009). Pragmatik dan Penelitian Pragmatik. Yogyakarta: Graha Ilmu.

Pomerantz, A. (1984). Agreeing and disagreeing with assessments: Some features of preferred/disprefered turn shapes. In J. Atkinson \& M. Heritage (Eds.), Structures in Social Action. Cambridge: Cambridge University Press, pp. 57-101.

Sifianou, M. (2012). Disagreement, face and politeness. Journal of Pragmatics 44, pp. 1554-1564. 
Xuehua, W. (2006). A Study of Strategy Use in Showing Agreement and Disagreement to Others Opinions. CELEA Journal 29. Vol V, pp. 55-65.

Yule, G. (1996). Pragmatics. New York: Oxford University Press.

\section{APPENDIX}

\section{QUESTIONAIRE}

My name is Nadia Yofa Laela Khoirunnisa. I am a student in the English Studies Program, Faculty of Cultural Sciences, Universitas Gadjah Mada, Indonesia. I am currently investigating how English native speaker students react to disagreeable situations for my graduating paper. I would be very grateful if you could help me and spend some time completing the questionnaire below.

\section{Personal Information:}

1. How old are you? (Please circle the appropiate letter $\mathrm{A}, \mathrm{B}$,or $\mathrm{C}$ )
A. $18-20$
B. 21-23
C. $24-26$

2. Are you a student?
A. Yes
B. No

3. Where are you from?
A. U. S. A.
B. Great Britain
C. Australia
D. Other:

Instruction: Please respond to each of the situations below as naturally as possible as if you are taking part in the conversations.

\section{Situation 1:}

You are shopping for dresses for a party with your best friends (Diana \& Hanna). Diana is choosing a dress you think is ugly and does not suit her, but Hanna says to Diana, "You need to buy it! You look so pretty. " How will you respond if you disagree?

\section{Situation 2 :}

You are in a car with your brother. You know the way very well, and you have to turn left at the next intersection, but your brother says: "I am turning right here. I think it's a short cut." However, you do not agree, so you say:

\section{Situation 3 :}

You get a bad score on your mid-term. Your father says to you: "You should focus only on your studies and leave all organizations or clubs you are involved in. "You do not want to follow what your father said so you say:

\section{Situation 4 :}

You sit next to a girl in the first day of orientation on campus. You never met her before. However, she suddenly says to you: "I have no idea why my parents sent me to this boring place again. I would rather work now and make money. Going to school is just useless and a waste of money. "You do not agree with what she said so you say:

\section{Situation 5 :}

You are sitting in a restaurant and the waiter is coming to you. The waiter says "Good evening. I am Carl and I will be your waiter tonight. For the special menu of this week, we are offering tuna cream soup. I recommend you to try it. It's so delicious. "However, you do not agree with the waiter, so you say:

\section{Situation 6 :}

You had to write a paper for one of your classes. You gave this paper to your teacher during class on Monday. Today is Thursday and the teacher returns the paper to the class. When he comes to your desk, he looks at you and says: "I'm sorry I didn't receive a paper from you so I gave you an F." You do not agree with what he said so you say: 